\title{
Candidate herbicides to control itchgrass (Rottboellia exaltata) in sugarcane fields'
}

\author{
Antonio Vélez-Ramos, ${ }^{2}$ Nelson Semidey ${ }^{3}$ and Nilsa M. Acin-Díaz"
}

\begin{abstract}
Field trials in 1986-87 were conducted in the humid sugarcane growing area of San Germán and under irrigation at the Lajas Research and Develapment Cenfer to evaluate several candidate herbicides for controlling itchgrass (Rotfboellia exalfata L.f.) in sugarcane fields. Terbutryn [2-(Tertbutylamino)-4-(ethylamino)-6- (methylthio-5-triazine] at 2.68, 5.35 and $10.70 \mathrm{~kg} / \mathrm{ha}$ as a direct post emergence application over itchgrass 15 to $20 \mathrm{~cm}$ tall provided excellent grass control with no injury to the crop. Asulam [methyl (4 amino phenyl) (sulfanyl)] carbamate at $2.09 \mathrm{~kg} / \mathrm{ha}$ showed a slow short-term action. With Terbutryn at $10.7 \mathrm{~kg} / \mathrm{ha}$ and the hand-weeded check plots significantly higher cane and sugar yields were abtained. Pendimethalin [N-(ethylpropyl)-3,4-dimethyl-2,6-dinitrobenzenamine] at $3.56 \mathrm{~kg} / \mathrm{ha}$ as a preemergence soil-incorporated application to a primaveras sugarcane crop was effective in controlling itchgrass. A single application of this product at $1.78 \mathrm{~kg} / \mathrm{ha}$ was markedly less effective. Imazapyr (2-[4,5 dihydro-4-methyl-4-(I-methylethyl)-5-0x0-1H-imidazolzyl]-3-pyridinecarboxylic acid) with 2-propanamine (1:1) salt at 0.125 and $0.25 \mathrm{~kg} / \mathrm{ha}$ controlled of itchgrass excellently.

Combinations of pendimethalin and imazapyr were effective in controlling grass weeds. The best cane tonnage and sugar yields were obtained from the hand-weeded plots and from combinations of pendimethalin and imazapyr. With pendimethalin of 0.89 and $1.78 \mathrm{~kg} / \mathrm{ha}$ and asulam at 2.98 $\mathrm{kg} / \mathrm{ha}$ there was very little effect from the herbicide treatments on increasing yield.
\end{abstract}

\section{RESUMEN}

Yerbicidas potenciales para combatir la yerba peluda en los cañaverales de Puerto Rico

En 1986-87 se establicieron dos experimentos de campo en la zona cañera húmeda de San Germán y en el Centro de Desarrollo e Investigaciones de Lajas (regadío) para evaluar varios herbicidas potenciales para combatir la yerba peluda (Rottboellia exaltata) en los cañaverales. Terbutrín en aplicaciones postemergentes dirigidas a la yerba peluda de 15 a $20 \mathrm{~cm}$. de altura la repimió eficarmente cuando se la aplicaron entre 2.68 y $10.70 \mathrm{~kg}$. $/ \mathrm{ha}$. Estas dosis no les causaron daños visibles al retoño en la zona húmeda de San Germán. Asulam usado como herbicida patrón fue lento y efímero en la represión de gramineas en este experimento. Las parcelas testigo, desyerbadas a mano y asperjadas con ferbutrín a 10.70 $\mathrm{kg}$./ha., produjeron significativamente más toneladas de caña y de azúcar

'Manuscript submitted to Editorial Board 26 February 1988.

${ }^{2}$ Associate Researcher, Department of Agronomy and Soils.

${ }^{3}$ Assistant Researcher, Department of Crop Protection.

${ }^{4}$ Associate Chemist, Department of Crop Protection.

"Spring planted. 
por hectárea que los demás tratamientos. Todas las parcelas tratadas con herbicidas produjeron significativamente más toneladas de caña por hectárea que el testigo sin desyerbar, excepto terbutrín a $1.34 \mathrm{~kg} . / \mathrm{ha}$.

Pendimetalin a razón de $3.56 \mathrm{~kg}$. $/$ ha., incorporado al terreno en aplicación preemergente, fue muy eficaz para reprimir la yerba peluda y otras gramíneas. Cuando se aplicó terbutrín a razón de $1.78 \mathrm{~kg}$. $/ \mathrm{ha}$., redujo marcadamente su eficacia a menos de $50 \%$ a las 10 semanas de aplicado. Imazapir a razón de 0.125 y $0.25 \mathrm{~kg}$. $/ \mathrm{ha}$. y en combinaciones de terbutrin fue excelente para la represión de gramíneas en esfe experimento en el Centro de Desarrollo e Investigaciones de Lajas. Los rendimientos más altos, en término de toneladas de caña y azúcar por hectárea, se obtuvieron con el testigo desyerbado a mano y las combinaciones de terbutrín e imazapir. El rendimiento del testigo sin desyerbar fue significativamente inferior a los tratamientos con herbicidas.

\section{INTRODUCTION}

Itchgrass (Rottboellia exaltata L.f.), a tall, heavy tillering annual grass, is rapidly becoming the most abundant weed in the sugarcane fields of Puerto Rico. The names itchgrass and "yerba peluda" were derived from the skin irritation caused by the short, needle-like hairs that protrude from the leaf sheaths.

Although apparently native to tropical Asia, itchgrass has become a major weed of sugarcane in Africa, the Philippine Islands, Trinidad, Louisiana and Puerto Rico (5). Infestations have also been reported in Australia, Colombia and Venezuela (6). Itchgrass was probably introduced in the southwestern sugarcane region of Puerto Rico around the midseventies. Seeds spread from infested areas to noninfested areas by flood waters, birds, rodents and man. Man is probably the primary spreader by transporting seed on farm machinery such as combines, sugarcane harvesters, tractors, trucks and mixed fertilizers.

Besides the economic threshold that itchgrass represents to the sugarcane industry of Puerto Rico, it has the potential of becoming a serious weed pest in other important crops such as vegetables.

Conflicting information is available concerning the chemical control of itchgrass in Puerto Rico. Herbicides such as ametryn [2-(ethylamino)-1(isopropylamino)-6-(methylthio)-S-triazine]; diuron, [3-,4-dichlorophenyl)-1-dimetylurea]; and dalapon, sodium salt of 2,2-(dichloropropionic acid), have been used with variable degrees of success. However, no data from controlled field experiments have been reported.

The present investigation was a joint effort between the Agxicultural Experiment Station of the University of Puerto Rico, the Ciba-Geigy Co., and the American Cyanamid Co. to evaluate several potential herbicides, with proven efficacy in controlling weed grasses elsewhere $(2,3,4,5)$, to control itchgrass in sugarcane fields in Puerto Rico, and to collect necessary field data for a possible registration of best candidates under section ( $24 \mathrm{c}$ ) of the Pesticide law. 


\section{MATERIALS AND METHODS}

In 1986-87 two field experiments were conducted covering humid and irrigated sugarcane lands in the southwestern part of the island. The experimental sites were heavily infested with itchgrass. The experimental design was randomized complete blocks with 4 replications and plots consisting of 4 cane rows $1.67 \mathrm{~m}$ apart and $6.1 \mathrm{~m}$ long with $1.50 \mathrm{~m}$ alleys between plots. Herbicidal treatments were applied with a $\mathrm{CO}_{2}$ pressurized stainless steel 1-gal pump preset at 35 psi to give a volume of spray of approximately $560 \mathrm{~L} / \mathrm{ha}$. Chemicals were applied early in the morning to avoid herbicide drift. Periodical field observations were made to evaluate the effect of herbicide treatments on weeds and crop. Weed control was estimated on the basis of a scale where $0=$ no control and $100=$ perfect control. Surfactant X-77 at $0.5 \%$ was added to all postemergence treatments. Broadleaf weeds were controlled with a 2,4-D application at $2.3 \mathrm{l} / \mathrm{ha}$. Fertilizer, pest control and other cultivation practices were those recommended in the "Conjunto Tecnológico para la Producción de Caña de Azúcar" (1). Major grass species included Rottboelia exaltata (L.), Sorghum halepense, (L.) Pers., Digitaria sanguinalis (L.) Scop. and Echinochloa colona (L.) Link.

Experiment 1 was established 10 April 1986 in a ratoon field planted to sugarcane variety PR 62-556. The location was a private farm in the humid zone of the municipality of San Germán with a mean annual rainfall of $1778 \mathrm{~mm}$. The soil is a Toa silty clay loam, which is one of the best soils for growing sugarcane in P. R. Herbicide treatments consisted of terbutryn at $1.34,2.68,5.35$ and $10.70 \mathrm{~kg} / \mathrm{ha}$ applied post-emergence over itchgrass 15 to $20 \mathrm{~cm}$ tall. Asulam at $2.98 \mathrm{~kg} / \mathrm{ha}$ was used as a standard herbicide treatment. Hand-weeded and unweeded check treatments were also included in all experiments. The experiment was harvested 3 February 1987. No sugarcane samples were collected for residue analysis of herbicides as indicated by the Ciba Geigy Co. representative.

Experiment 2 was established at the Lajas Research and Development Center located in the southwestern region of the island with average annual rainfall around $762 \mathrm{~mm}$, and where supplementary irrigation is necessary for adequate sugarcane growth. Sugarcane variety PR 1070 was planted 15 April 1986 as a primavera crop. Pendimenthalin was incorporated into the soil with sprinkler irrigation 18 April 1986. Imazapyr was applied as early postemergence treatment 6 May 1986.

Herbicide treatments were pendimenthalin at $0.89,1.78$ and $3.56 \mathrm{~kg} /$ ha; imazapyr at 0.125 and $0.25 \mathrm{~kg} / \mathrm{ha}$; asulam at $2.98 \mathrm{~kg} / \mathrm{ha}$. Pendimethalin at 0.89 and $1.78 \mathrm{~kg} / \mathrm{ha}$ applied preemergence was mixed with imazapyr at 0.125 and $0.25 \mathrm{~kg} / \mathrm{ha}$ applied sequentially, respectively. The experiment was harvested 22 April 1987 and data collected for determining 
cane tonnage and sugar yields. Sugarcane samples treated with pendimethalin were secured for residue analysis.

\section{RESULTS AND DISCUSSION}

Tables 1 and 2 present weed control data from the experiment located in San Germán. Terbutryn at rates above $2.68 \mathrm{~kg} /$ ha provided excellent weed control in this ratoon crop. When applied directly over 15 to $20 \mathrm{~cm}$ tall grasses it controlled itchgrass until sugarcane closed-in. Applications of the product at $1.34 \mathrm{~kg} / \mathrm{ha}$ failed to show any significant control of itchgrass or other grasses at this experimental site. Asulam had a very slow weed control effect which disappeared 8 weeks after application. Best weed control with terbutryn was obtained at the higher rates without any visible phytotoxicity to the crop.

In the primavera crop trial at Lajas (table 3), pendimethalin at 3.56 $\mathrm{kg} / \mathrm{ha}$, imazapyr at 0.125 and $0.25 \mathrm{~kg} / \mathrm{ha}$ and the combinations of both herbicides controlled itchgrass very effectively as well as other gxass weeds. One single application of the above herbicide treatment was sufficient to provide good grass control until crop closed in. Pendimethalin at the lower rates $(0.89$ and $1.78 \mathrm{~kg} / \mathrm{ha})$ showed low persistence and short-term weed control. Asulam at $2.98 \mathrm{~kg} / \mathrm{ha}$ was ineffective in controlling grass weeds in this trial.

Data on counts of germinating grass weeds in the treated plots indicated that the herbicide treatments were effective in suppressing the regrowth of such weeds, except for the treatments of asulam and pendimethalin at $0.89 \mathrm{~kg} / \mathrm{ha}$ (table 4). The information with regard to the number of sugarcane shoots per $6.1 \mathrm{~m}$-row was erratic. Increasing rates of pendimethalin seemed to increase the number of germinating shoots; however, the differences were not statistically significant. Again, treatments in which imazapyr was included were associated with higher shoot

TABLE 1.-Effect of postemergence herbicide applications on the control of weeds in sugarcane. Ratoon crop, San Germain

\begin{tabular}{|c|c|c|c|c|}
\hline \multicolumn{2}{|c|}{ Treatment } & \multicolumn{3}{|c|}{ Weeks after treatment application } \\
\hline Herbicide & Rate & 3 & 5 & 8 \\
\hline & kgtha & \multicolumn{3}{|c|}{ \%ocontrols } \\
\hline Terbutryn & 1.33 & 75.0 & $<50$ & $<50$ \\
\hline Terbutryn & 2.68 & 97.0 & 82.0 & 80.0 \\
\hline Terbutryn & 5.35 & 97.5 & 95.0 & 90.3 \\
\hline Terbutryn & 10.70 & 98.0 & 97.0 & 92.5 \\
\hline Asulam & 2.98 & $<50$ & 75.0 & $<50$ \\
\hline \multicolumn{2}{|c|}{ Hand weeded check } & 100 & 100 & 100 \\
\hline \multicolumn{2}{|c|}{ Unweeded check } & 0 & 0 & 0 \\
\hline
\end{tabular}

'Based on a scale where $0=$ no control; $100=$ perfect control. 
TABLE 2.-Effect of herbicide treatments on Rotboellia exaltata and other grasses. Ratoun crop, San Germán

\begin{tabular}{lrccc}
\hline \multicolumn{1}{c}{ Treatment } & & $\begin{array}{c}\text { Rotboellia } \\
\text { exaltata }\end{array}$ & $\begin{array}{c}\text { Other } \\
\text { grasses }\end{array}$ & Total \\
\hline Herbicide & Rate & & & \\
\hline & kg/ha & $9.8 \mathrm{ab}^{2}$ & $2.8 \mathrm{a}$ & $12.6 \mathrm{bc}$ \\
Terbutryn & 1.34 & $9.5 \mathrm{ab}$ & $0.8 \mathrm{a}$ & $10.3 \mathrm{bc}$ \\
Terbutryn & 2.68 & $2.8 \mathrm{~b}$ & $3.2 \mathrm{a}$ & $6.0 \mathrm{c}$ \\
Terbutryn & 5.35 & $1.5 \mathrm{~b}$ & $0.3 \mathrm{a}$ & $1.8 \mathrm{c}$ \\
Terbutryn & 10.70 & $15.0 \mathrm{a}$ & $5.0 \mathrm{a}$ & $20.0 \mathrm{ab}$ \\
Asulam & 2.98 & $20.0 \mathrm{a}$ & $5.8 \mathrm{a}$ & $25.8 \mathrm{a}$ \\
Unweeded check & & &
\end{tabular}
tion.

'Mean number of plants in $0.5 \mathrm{~m}^{2}$ of few replications, 10 weeks after treatment applica${ }^{2}$ Means with same letters do not differ significantly at $P=0.05$.

counts. These treatment differences seemed to be associated with weed competition rather than with any other factor.

Table 5 presents sugarcane yield and quality obtained from the San Germán experiment. Terbutryn at $10.70 \mathrm{~kg} / \mathrm{ha}$ together with the handweeded check plots produced the highest yield with 8.7 tons/ha. This cane yield was significantly higher than the cane yields of all other herbicide treatments, except for terbutryn at $1.34 \mathrm{~kg} / \mathrm{ha}$ which produced only 13.8 tons of cane per hectare. Laboratory analysis for percentage sugar yield (sucrose 96) based on the Pol-ratio method, although a little high, was comparable with other experimental results based on this

TABLE 3.-Effect of herbicide treatments on the control of grass weeds. Primavera crop, Lajas

\begin{tabular}{|c|c|c|c|c|c|}
\hline \multicolumn{2}{|c|}{ Treatment } & \multicolumn{4}{|c|}{ Weeks after treatment application } \\
\hline \multirow[t]{2}{*}{ Herbicide } & Rate & 3 & 6 & 10 & 14 \\
\hline & $\mathrm{kg} / \mathrm{ha}$ & \multicolumn{4}{|c|}{$\%$ control } \\
\hline Pendimethalin & 0.89 & 90.0 & 50 & 50 & 50 \\
\hline Pendimethalin & 1.78 & 93.0 & 61.0 & 50 & 50 \\
\hline Pendimethalin & 3.56 & 99.0 & 82.5 & 71.3 & 64.5 \\
\hline Imazapyr & 0.125 & 89.0 & 88.8 & 78.8 & 62.5 \\
\hline Imazapyr & 0.25 & 98.0 & 97.8 & 90.8 & 80.0 \\
\hline Pendimethalin & 0.89 & & & & \\
\hline + Imazapyr & 0.125 & 94.0 & 94.0 & 93.0 & 80.0 \\
\hline \multicolumn{6}{|l|}{ Pendimethalin } \\
\hline + Imazapyr & 0.25 & 99.0 & 98.5 & 95.5 & 89.3 \\
\hline Asulam & 2.98 & 50 & 50 & 50 & 50 \\
\hline \multicolumn{2}{|c|}{ Hand weeded check } & 100 & 100 & 100 & 100 \\
\hline \multicolumn{2}{|c|}{ Unweeded check } & 0 & 0 & 0 & 0 \\
\hline
\end{tabular}

'Mean percentage control of four replications based on a scale where $0=$ no control, $100=$ perfect control. 
TABLE 4.-Effect early postemergence herbicide treatments on sugarcane and grass weeds. Primavera crop, Lajas

\begin{tabular}{|c|c|c|c|}
\hline \multicolumn{2}{|c|}{ Treatment } & \multicolumn{2}{|c|}{ Number of germinated shorts of } \\
\hline Herbicide & Rate & Grass weeds' & Sugarcane $^{2}$ \\
\hline & kglha & & \\
\hline Pendimethalin & 0.89 & 42 & $31 \mathrm{~d}^{3}$ \\
\hline Pendimethalin & 1.78 & 7 & $56 \mathrm{~cd}$ \\
\hline Pendimethalin & 3.56 & 7 & $65 \mathrm{bcd}$ \\
\hline Imazapyr & 1.25 & 7 & 131 a \\
\hline \multirow{2}{*}{$\begin{array}{l}\text { Imazapyr } \\
+ \text { Pendimethalin }\end{array}$} & 0.25 & 3 & 128 a \\
\hline & 0.89 & & \\
\hline \multirow{2}{*}{$\begin{array}{l}\text { Imazapur } \\
+ \text { Pendimethalin }\end{array}$} & 0.125 & 2 & $130 \mathrm{a}$ \\
\hline & 1.78 & & \\
\hline Imazapyr & 0.25 & 1 & $101 \mathrm{ab}$ \\
\hline Asulam & 2.98 & 55 & $65 \mathrm{bed}$ \\
\hline \multicolumn{2}{|l|}{ Unweeded check } & 61 & $27 \mathrm{~d}$ \\
\hline \multicolumn{2}{|c|}{ Hand weeded check } & 0 & $90 \mathrm{abd}$ \\
\hline
\end{tabular}

'Mean number of plants in $0.5 \mathrm{~m}^{2}$ area for four replications 9 weeks after treatment application.

${ }^{2}$ Mean number of germinated shorts in a $6.1 \mathrm{~m}$ row for four replications 9 weeks after treatment application.

${ }^{3}$ Means with same letters do not differ significantly at $P=0.05$.

method of sucrose analysis. Yield (tons sugar/ha) followed the same trend as yield of tons cane/ha since there was very little variation on the mean percentage yield average. The coefficient of variation (cv) was high for both tons cane (33.78) and tons sugar (35.37).

Best results with terbutryn expressed as weed control and yield were obtained with the highest rate $(10.70 \mathrm{~kg} / \mathrm{ha})$, which is four times the

TABLE 5.-Effect of herbicide treatments on cane and sugar yields. Ratoon crop, San Germán

\begin{tabular}{|c|c|c|c|c|}
\hline \multicolumn{2}{|c|}{ Treatment } & \multirow[b]{2}{*}{ Tons cane/ha } & \multirow{2}{*}{$\begin{array}{l}\text { Yield-96 } \\
\text { \% Sucrose }\end{array}$} & \multirow[b]{2}{*}{ Tons sugar/ha } \\
\hline Herbicide & Rate & & & \\
\hline & $\mathrm{kg} / \mathrm{ha}$ & & & \\
\hline Terbutryn & 10.70 & $87.7 \mathrm{a}^{1}$ & $12.21 \mathrm{a}$ & $10.69 \mathrm{a}$ \\
\hline \multicolumn{2}{|c|}{ Hand weeded } & $87.7 \mathrm{a}$ & $11.55 \mathrm{a}$ & $9.93 \mathrm{a}$ \\
\hline Asulam & 2.98 & $47.9 \mathrm{~b}$ & $12.27 \mathrm{a}$ & $6.00 \mathrm{~b}$ \\
\hline Terbutryn & 5.35 & $47.6 \mathrm{~b}$ & $11.16 \mathrm{ab}$ & $5.36 \mathrm{~b}$ \\
\hline Terbutryn & 2.68 & $41.0 \mathrm{~b}$ & $9.46 \mathrm{~b}$ & $3.80 \mathrm{~b}$ \\
\hline \multicolumn{2}{|c|}{ Unweeded check } & $24.4 \mathrm{bc}$ & $10.07 \mathrm{~b}$ & $3.11 b c$ \\
\hline Terbutryn & 1.34 & $13.8 \mathrm{c}$ & $10.53 \mathrm{ab}$ & $1.48 \mathrm{c}$ \\
\hline \multicolumn{2}{|l|}{ c.v. } & 33.78 & 11.68 & 35.37 \\
\hline
\end{tabular}

'Means with letters in common do not differ significantly at $P=0.05$. 
TABLE 6.-Effect of herbicide treatments on cane and sugar yields. Primavera crop, Lajas

\begin{tabular}{llccc}
\hline Herbicide & Rate & Tons cane/ha & \% Rendiment & Tons sugarha \\
\hline & kg/ha & & & \\
Hand weeded & & $141.5 \mathrm{a}^{\prime}$ & $13.04 \mathrm{a}$ & $18.38 \mathrm{a}$ \\
Pendimethalin & 0.89 & & & \\
+ Imazapyr & 1.125 & $137.1 \mathrm{a}$ & $12.13 \mathrm{ab}$ & $16.62 \mathrm{a}$ \\
Pendimethalin & 1.78 & & & \\
+ Imazapyr & 0.25 & $151.1 \mathrm{ab}$ & $13.69 \mathrm{a}$ & $15.61 \mathrm{ab}$ \\
Imazapyr & 0.25 & $98.8 \mathrm{~b}$ & $13.22 \mathrm{a}$ & $12.70 \mathrm{~b}$ \\
Pendimethalin & 3.56 & $100.5 \mathrm{~b}$ & $12.58 \mathrm{ab}$ & $12.67 \mathrm{~b}$ \\
Imazapyr & 0.125 & $88.9 \mathrm{bc}$ & $13.28 \mathrm{a}$ & $11.46 \mathrm{~b}$ \\
Pendimethalin & 1.78 & $58.9 \mathrm{c}$ & $12.09 \mathrm{ab}$ & $7.21 \mathrm{c}$ \\
Pendimethalin & 0.89 & $64.0 \mathrm{c}$ & $10.62 \mathrm{~b}$ & $6.72 \mathrm{c}$ \\
Asulam & 2.98 & $51.1 \mathrm{c}$ & $11.93 \mathrm{ab}$ & $6.02 \mathrm{c}$ \\
$\quad$ Unweeded check & & $23.5 \mathrm{~d}$ & $11.39 \mathrm{ab}$ & $2.79 \mathrm{~d}$ \\
$\quad$ c.v. & & 23.07 & 10.30 & 23.79 \\
\hline
\end{tabular}

'Means with letters in common do not differ significantly at $P=0.05$.

recommended rate $(2.68 \mathrm{~kg} / \mathrm{ha})$. When terbutryn was applied at the recommended rate weed control was good, but sugarcane yield was poor. However, the yield data must be handled with caution because of the high variability in this experiment.

The tons of cane/ha produced by the hand weeded check plots in the primavera experiment at Lajas were the highest, but were not significantly different from those yielded by the plots with combinations of pendimentalin and imazapyr (table 6). Pendimethalin at the recommended rate of $1.78 \mathrm{~kg} / \mathrm{ha}$ yielded significantly less cane per ha (58.9 tons) than the above mentioned treatments, and statistically, not better than asulam at $2.98 \mathrm{~kg} / \mathrm{ha}$. Herbicide treatments had little effect on cane sucrose 96 content. In each treatment, yield of sugar/ha was commensurate with tons cane/ha.

A comparison of field ratings for weed control (tables 1 and 2) and sugar yield (table 5) for the San Germán experiment shows a correlation between the two variables: high sugar yields associated with high weed control ratings, and low sugar yields with the low rating, except for asulam at $2.98 \mathrm{~kg} / \mathrm{ha}$. This correlation is even higher for the Lajas experiment (tables 3 and 6). In general, weeds were controlled best when a preemergence herbicide (pendimethalin) and an early-post-emergence (imazapyr) were applied sequentially. Similar results were reported with metribuzin (preemergence) followed by asulam (postemergence) (7).

\section{LITERATURE CITED}

1. Anonymous. 1976. Conjunto Tecnológico para la producción de azúcar. Esta. Exp. Agric. Univ. P. R. Bol. 103. 
2. Fine, R. R., T. R. Peoples and D. R. Clarbante, 1983. AC 252, 925-a new broad-spectrum herbicide. Asian Pac. Weed Sci. Soc. pp. 436-49.

3. Millhollon, R. W., 1972. Soil-incorporated trifluralin for controlling weeds in sugarcane. Proc. Am. Soc. Sugar Cane Technol. 2: 41-4.

4. _- 1976. Asulam Johnsongrass control in sugarcane. Weed. Sci. 24: 496-99.

5. ㄴ, 1980. Itchgrass-a weed of worldwide concern. The Sugar Joumal. 43: 7 December.

6. - 1983 . Late-season weed control in sugarcane with herbicides applied at lay-by. $J$. Am. Soc. Sugar Cane Technol. 2: 17-21.

7. Semidey, N. and L. Almodóvax, 1986. Asulam and other postemergence herbicides for sugarcane. J. Agric. Univ. P. R., 70 235-43. 